\title{
REASSESSMENT OF LAPLATASAURUS ARAUKANICUS (SAUROPODA: TITANOSAURIA) FROM THE UPPER CRETACEOUS OF PATAGONIA, ARGENTINA
}

\author{
PABLO ARIEL GALLINA ${ }^{1,3}$ AND ALEJANDRO OTERO2,3 \\ 1Área de Paleontología, Fundación Félix de Azara CEBBAD-Universidad Maimónides, Hidalgo 775 7º piso, C1405BCK Buenos Aires, Argentina. pablogallina@gmail.com \\ 2División Paleontología Vertebrados, Museo de La Plata. Paseo del Bosque s/n, B1900FWA La Plata, Argentina. alexandros.otero@gmail.com \\ ${ }^{3}$ CONICET - Consejo Nacional de Investigaciones Científicas y Técnicas.
}

\begin{abstract}
The original material assigned to Laplatasaurus araukanicus Huene come from five different localities in northern Patagonia (Argentina) where the Upper Cretaceous (Campanian) lies exposed. This material includes several postcranial bones from multiple specimens and showing different conditions of preservation, often lacking anatomical overlap. The taxonomic status of the taxon is further obscured by the absence of quarry maps of the multiple localities (lacking the recognition of associated materials), and a proper designation of type material in its original description. After Huene, new material was assigned to this taxon, although none of it resolved the existing taxonomic issues. In 1979, the designation of a lectotype (one tibia and one fibula) was the first stage in the nomenclatural stabilization of the species. However, the assignment of the remaining material to $L$. araukanicus remained uncertain. Here we review all the material hitherto assigned to this taxon in order to clarify its taxonomic status. We also provide a re-description of the lectotype and discuss the taxonomic identification of material previously referred to this taxon. Lastly we include it for the first time in an updated phylogenetic data matrix. Laplatasaurus araukanicus is retained only for the lectotype. The material from Rancho de Ávila is referred to cf. Bonitasaura sp. because they share diagnostic features and are stratigraphically congruent. The remaining material is referred as Lithostrotia indet. A phylogenetic analysis nests Laplatasaurus within Titanosauria in a clade formed by ((Laplatasaurus + Uberabatitan) + (Bonitasaura + (Futalognkosaurus + Mendozasaurus))).
\end{abstract}

Key words. Sauropoda. Titanosauria. Laplatasaurus. Lectotype. Late Cretaceous. Patagonia.

Resumen. REEVALUACIÓN DE LAPLATASAURUS ARAUKANICUS(SAUROPODA: TITANOSAURIA) DEL CRETÁCICO SUPERIOR DE PATAGONIA, ARGENTINA. El material original asignado a Laplatasaurus araukanicus Huene proviene de cinco localidades del Cretácico Superior (Campaniano) del norte de Patagonia, Argentina. Este material incluye numerosos huesos postcraneanos de múltiples especímenes y con diferentes condiciones de preservación, generalmente carentes de superposición anatómica. El estatus taxonómico del taxón es incierto debido a la ausencia de mapas de campo de las múltiples localidades (impidiendo el reconocimiento de materiales asociados), y una apropiada designación de material tipo en su descripción original. Con posterioridad al trabajo de Huene, se asignó nuevo material a este taxón, acarreando problemas taxonómicos. En 1979, la designación de un lectotipo (una tibia y una fíbula) fue el primer paso hacia la estabilización nomenclatural de la especie. Sin embargo, la asignación taxonómica del resto del material asignado a Laplatasaurus araukanicus permanecía sin una resolución. Aquí, revisamos todo el material que alguna vez fuera asignado a este taxón para poder establecer el estatus taxonómico del mismo. Para ello proveemos una re-descripción del lectotipo, discutimos la identificación taxonómica del material, e incluimos por primera vez al taxón en una matriz filogenética actualizada. Laplatasaurus araukanicus se reserva solo para el material lectotipo. El material de Rancho de Ávila se asigna a cf. Bonitasaura sp. por congruencias en la presencia de caracteres diagnósticos y la procedencia estratigráfica. Los otros restos son referidos como Lithostrotia indet. El análisis filogenético muestra la posición anidada de Laplatasaurus dentro de Titanosauria en un clado formado por ((Laplatasaurus + Uberabatitan) + (Bonitasaura + (Futalognkosaurus + Mendozasaurus))).

Palabras clave. Sauropoda. Titanosauria. Laplatasaurus. Lectotipo. Cretácico Superior. Patagonia.

LATE Cretaceous sauropod diversity was dominated by titanosaurs (Powell, 2003; Barrett and Upchurch, 2005). Recorded on all continental land-masses (Hunt et al., 1994; Cerda et al., 2012), this group brings together relatively small-sized (six meters long) taxa weighing one ton (Jianu and Weishampel, 1999), and tetrapods weighing c. 80 tons
(Mazzetta et al., 2004), the largest land animals ever inhabiting the Earth.

A timeless work, Huene's monograph (published in 1929 as a special volume of the "Anales del Museo de la Plata") is still an important source of knowledge on several Cretaceous titanosaurs from Patagonia. That work includes ex- 
haustive descriptions and figures, not only of material belonging in known species [e.g., 'Titanosaurus' (=Neuquensaurus) australis] but also of several new remains nominated therein (e.g., Antarctosaurus wichmannianus, Laplatasaurus araukanicus).

The material assigned to Laplatasaurus araukanicus by Huene (1929a) comes from different localities in northern
Patagonia (Fig. 1), although most bones are from Cinco Saltos and Rancho de Ávila, in Río Negro Province (Bonaparte and Gasparini, 1979). The remains include several postcranial bones from multiple specimens and obviously different conditions of preservation. Huene (1929a) described all the material, providing the geographic or collection provenance of each specimen [e.g., 'Del material de

(1)

(4)
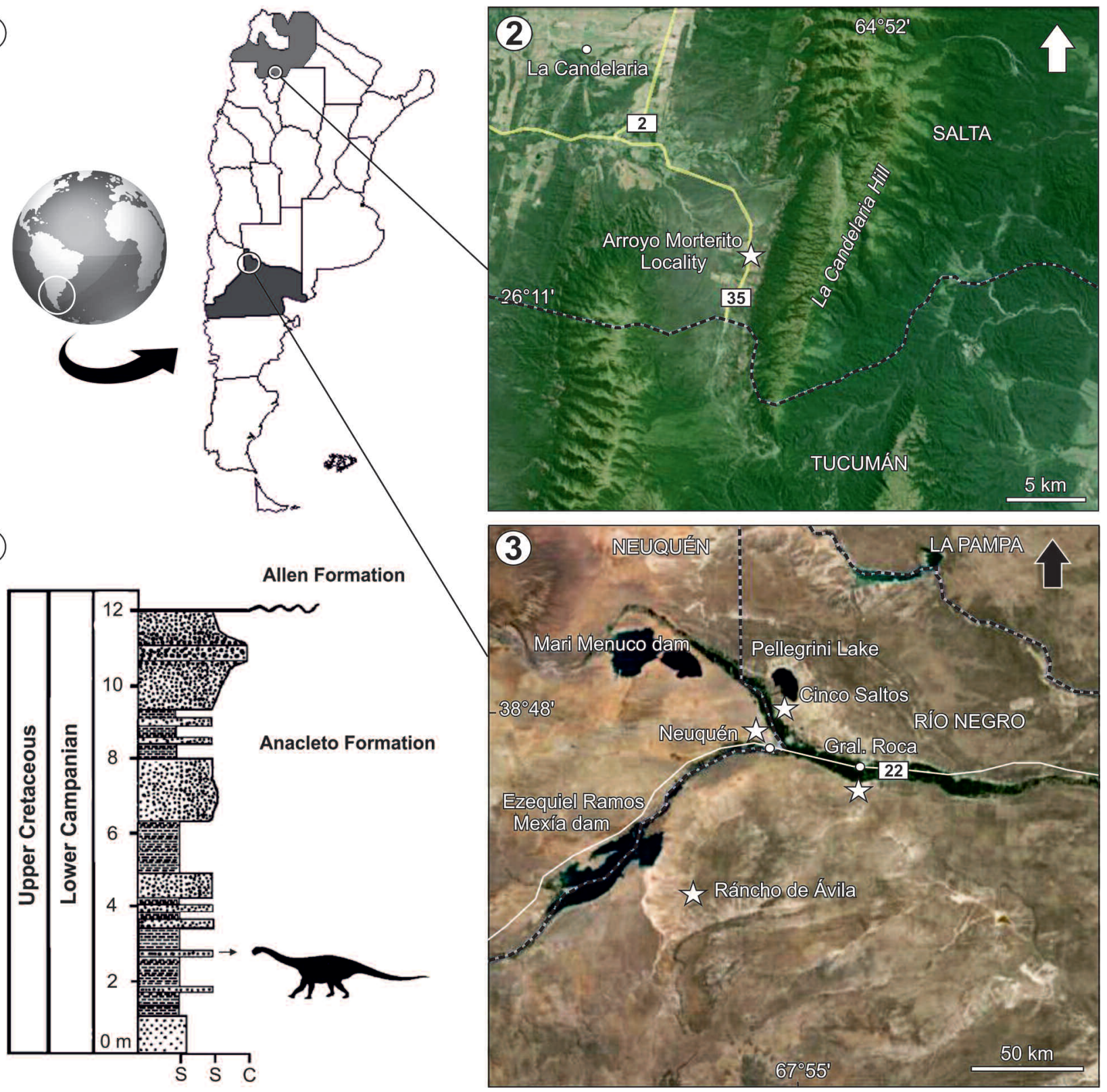

Figure 1. Location map showing the occurrence of the lectotype of Laplatasaurus araukanicus and previously referred specimens. 1, map of Argentina, with Salta (north) and Río Negro (middle) provinces highlighted. 2, Arroyo Morterito, Salta Province. 3, Localities of Laplatasaurus and previously referred specimens, Río Negro Province. 4, Laplatasaurus araukanicus lectotype approximate stratigraphic location (based on description of Huene, 1929a). Stratigraphic column adapted from Salgado et al. (2005). 
Lydekker' (From Lydekker's material), 'Vértebras de Rancho de Ávila' (Vertebrae from Rancho de Ávila), 'Individuo joven de Cincos Saltos' (Young specimen from Cinco Saltos)]. However, he provided no particular quarry map or any accurate stratigraphic details and/or information concerning the skeletal association of most of the remains (only one caudal series of ten vertebrae is mentioned as associated). Moreover, his specific assignation was based on the size and robustness of the bones when compared with other titanosaurs such as 'Titanosaurus' (=Neuquensaurus) australis rather than on the recognition of diagnostic characters, type material or associated specimens. According to Bonaparte and Gasparini (1979, p. 400), this situation represents a taxonomic problem because 'ignoramos si la totalidad del material asignado a Laplatasaurus araukanicus corresponde al mismo género y especie, o si corresponde a formas no reconocidas' (we ignore if all the material assigned to Laplatasaurus araukanicus belongs to the same genus and species, or to unknown forms). Considering Huene's skills as an accomplished anatomist, we understand that his decision to bring together all the remains under Laplatasaurus araukanicus was skewed by the then very poorly known South American sauropod diversity.

In the same year, Huene (1929b) referred material from Uruguay to Laplatasaurus araukanicus but he did not provide a description or figures. These fragmentary remains were later referred as Titanosauridae indet. by Powell (2003). Powell (1979) assigned material from Arroyo Morterito (Salta Province, Argentina) to Laplatasaurus sp. based on similarities observed in the appendicular bones, although they were later referred by him as Titanosauridae indet. (Powell, 2003). In his review of South American titanosaurs, Powell (2003) referred part of Huene's (1929a) original material to the genus Titanosaurus, in the new combination $\mathrm{Ti}$ tanosaurus araukanicus (the material from Cinco Saltos) and part to Titanosauridae indet. (the material from General Roca, Neuquén city and Rancho de Ávila). Besides, he included new material collected in 1975 (an articulated tail) at Cinco Saltos in the hypodigm of the species. Since then, this species has been discussed by several authors (Mclntosh, 1990; Bonaparte, 1996; Salgado, 2003; Wilson and Upchurch, 2003; Upchurch et al., 2004), all of who recommended caution regarding its long-standing taxonomic problems.
In this paper we review all the material hitherto assigned to Laplatasaurus araukanicus in order to establish a proper systematic status for the taxon. First, we present a redescription of the lectotype of Laplatasaurus araukanicus, providing new autapomorphies for this species. Second, we discuss the validity of material previously referred to the genus and provide a tentative taxonomic assignment for it. Lastly, we include -for the first time- the lectotype of Laplatasaurus araukanicus in an updated phylogenetic data matrix in order to clarify the phylogenetic position for this taxon.

Institutional Abbreviations. FMNH, Field Museum of Natural History, Chicago, USA; IANIGLA-PV, Instituto Argentino de Nivología, Glaciología y Ciencias Ambientales, Mendoza, Argentina; MACN, Museo Argentino de Ciencias Naturales "Bernardino Rivadavia", Buenos Aires, Argentina; MDE, Museé des Dinosaures d`Espéraza, Aude, France; MLP-Av, Museo de La Plata, Rancho de Ávila Collection, La Plata, Argentina; MLP-CS, Museo de La Plata, Cinco Saltos Collection, La Plata, Argentina; MLP-Ly, Museo de La Plata, Lydekker's Collection, La Plata, Argentina; MPCA, Museo Provincial "Carlos Ameghino", Cipolletti, Río Negro, Argentina; MUCPv, Museo de Geología y Paleontología de la Universidad Nacional del Comahue, Neuquén, Argentina; PVL, Collection of Vertebrate Paleontology of Instituto "Miguel Lillo", Tucumán, Argentina.

\section{SYSTEMATIC PALEONTOLOGY}

Dinosauria Owen, 1842

SAUROPOda Marsh, 1878

Titanosauriformes Salgado, Coria and Calvo, 1997

SOMPHOSPONDYLI Wilson and Sereno, 1998

TITANOSAURIA Bonaparte and Coria, 1993

Laplatasaurus Huene, 1929a

Type species. Laplatasaurus araukanicus Huene, 1929a.

Laplatasaurus araukanicus Huene, 1929a

Figure $2,3,4.2,5.2$

1929a Laplatasaurus araukanicus Huene, p. 53, figs. 13-30.

1979 Laplatasaurus araukanicus Huene; Bonaparte and Gasparini, 1979, p. 399. 
1986 Titanosaurus araukanicus (Huene, 1929); Powell, 1986, p. 82, pl. 5.

1990 Laplatasaurus araukanicus Huene; McIntosh, 1990, p. 395, fig. 16.8.

1996 Titanosaurus araukanicus (Huene, 1929); Bonaparte, 1996, p. 103, fig. 35.

2002 Titanosaurus araukanicus (Huene, 1929); Salgado and García, 2002, p. 212, fig. 1.

2003 Titanosaurus araukanicus (Huene, 1929a); Powell, 2003, p. 22, pl. 5.

2003 Laplatasaurus araukanicus Huene; Wilson and Upchurch, p. 141, fig. 12
Lectotype. MLP-CS 1128, right tibia and MLP-CS 1127, right fibula (Figs. 2, 3).

Comments. Bonaparte and Gasparini (1979) mentioned this taxon when referring material from the localities mentioned above to Laplatasaurus araukanicus. Later, Powell (2003) and Salgado and Bonaparte (2007) defined as hypodigm of this species material from Cinco Saltos housed in the MLP-CS together with an articulated caudal series from Cinco Saltos
(1)

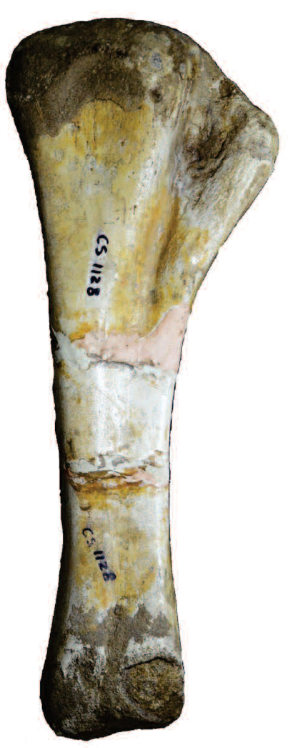

(2)



3

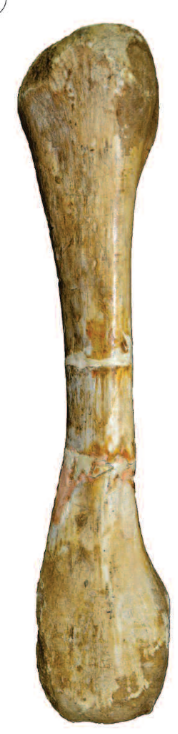

(4)

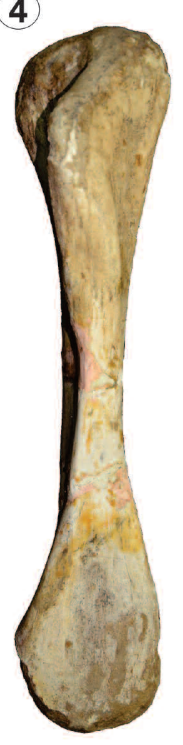

(5)

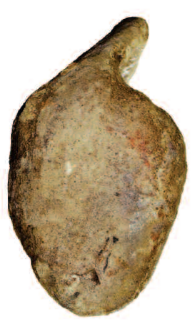

(6)

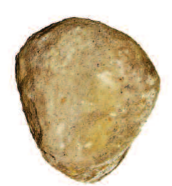

7

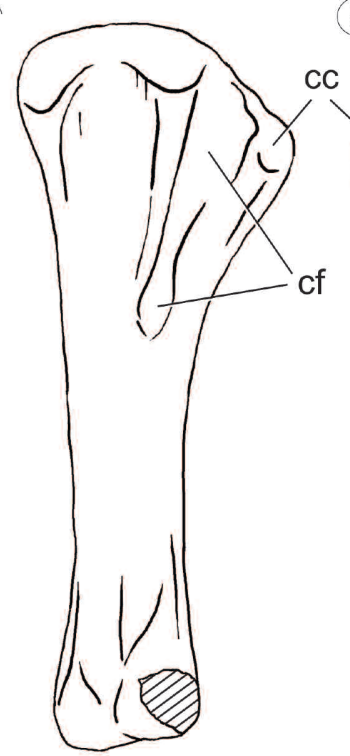

8

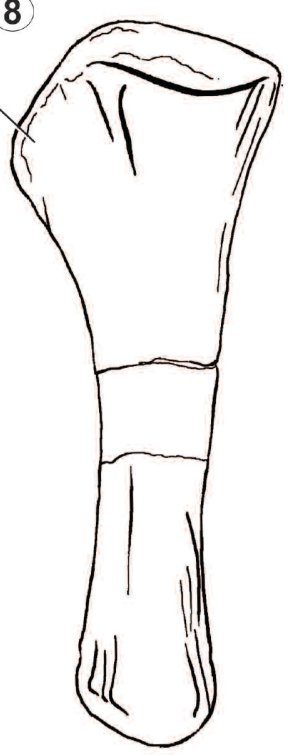

(9)

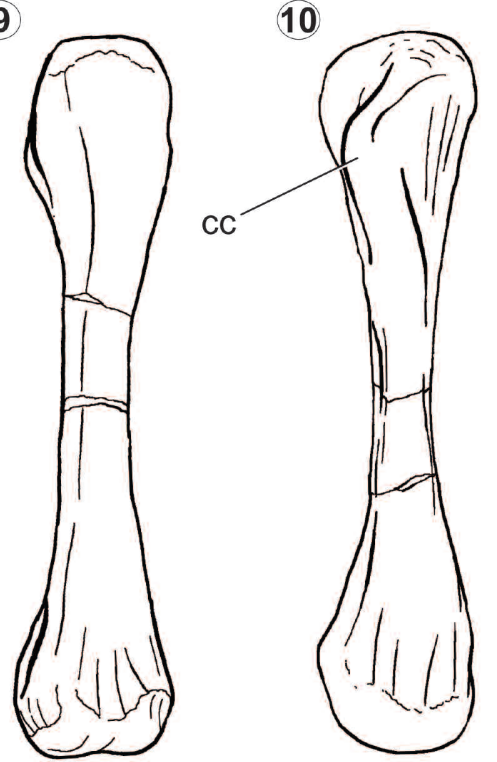

11

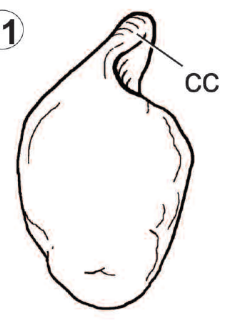

12



Figure 2. Laplatasaurus araukanicus lectotype, MLP-CS 1128; 1, 7, right tibia in lateral view; 2, 8, medial view; 3, 9, posterior view; 4, 10, anterior view, 5, 11, proximal view; 6, 12, distal view. Abbreviations: cc, cnemial crest; cf, cnemial fossa. Scale bar= $10 \mathrm{~cm}$. 
housed in the Cipoletti Museum (MPCA 1501). Despite this, in this contribution we provide evidence that supports the removal of such material from Laplatasaurus araukanicus (see Discussion).

Revised diagnosis. Laplatasaurus araukanicus differs from other derived titanosauriforms by the presence of the following combination of characters (autapomorphies denoted with an asterisk): (1) slender tibia with deep cnemial fossa, extending more than one third the length of the shaft*; (2) fibula with extremely developed anterior fossa on the proximal end, laterally delimited by a thick margin* (a slightly less developed fossa is present in Uberabatitan and Jainosaurus); (3) fibula with a well-developed lateral tuberosity, similar to that one present in Neuquensaurus.

Stratigraphic occurrence and geographic location. The material referred by Huene to Laplatasaurus araukanicus (1929a) comes from different Patagonian localities (e.g., close to Neuquén city in Neuquén Province; General Roca, Rancho de Ávila and Cinco Saltos in Río Negro Province; Sierra de San Bernardo in Chubut Province). Considering that material referable to Laplatasaurus araukanicus is restricted in this contribution only to the lectotype designated by Bonaparte and Gasparini (1979), the only valid geographic occurrence for this taxon is thus Cinco Saltos (Fig. 1.3; Huene, 1929a, p. 5). Expeditions commissioned by the La Plata Museum between 1921 and 1923 to multiple excavating localities in the area provided the raw material for Huene's monograph. The specific locality where Laplatasaurus was collected lies approximately $3 \mathrm{~km}$ west from the city of Cinco Saltos, next to the INDUPA (Patagonic Industries) quarry (Powell, 2003).

Regarding the stratigraphic position, Huene (1929a, p. 12) provided stratigraphic data recorded by Wichmann (1922), mentioning the occurrence of the dinosaur remains below the 'Salamanca stage' (late 'Senonian'). The stratigraphic description provided by Huene (1929a, p. 12) consists basically of an alternation of pelitic and psamitic beds, of which bed ' $d$ ' (approximately 3 meters above ground level) yielded dinosaur remains. Such a stratigraphic description is congruent with the section published by Salgado et al. (2005), in which Neuquensaurus remains occur at a stratigraphic level equivalent to the Rio Colorado Subgroup (top of the Anacleto Formation, Coloradan assemblage sensu Leanza et al., 2004; contra Bonaparte and Gasparini, 1979; Leanza, 1999, Powell, 2003), early Campanian (Leanza, 1999; Leanza and Hugo, 2001) (Fig. 1.4).

\section{DESCRIPTION}

In this section we describe the material here assigned to Laplatasaurus araukanicus (lectotype; Tab. 1). For the long bone descriptions we provide the Robustness Index (RI) as the average of the greatest widths of the proximal end, mid-shaft and distal end of the element/length of the element (Wilson and Upchurch, 2003).

Tibia. A complete right tibia is part of the lectotype (Fig. 2). It is an elongate bone with expanded proximal and distal ends (RI: 0.22). The anteroposteriorly expanded proximal end and the distal half with almost straight anterior and posterior borders resemble similar features in other titanosaurs such as Antarctosaurus (MACN 6904), Aeolosaurus (MJG-R1), Gondwanatitan (Kellner and Azevedo, 1999), Rapetosaurus (FMNH-PR 2209), Mendozasaurus (IANIGLAPV 065/084), Jainosaurus (Wilson et al., 2011) and Boni-

TABLE 1. Laplatasaurus araukanicus. Selected measurements in mm.

\begin{tabular}{lcccc}
\hline & Length & $\begin{array}{c}\text { Proximal end anteroposterior } \\
\text { diameter }\end{array}$ & $\begin{array}{c}\text { Proximal end mediolateral } \\
\text { diameter }\end{array}$ & $\begin{array}{c}\text { Midshaft anteroposterior } \\
\text { diameter }\end{array}$ \\
\hline Tibia & 640 & 230 & 135 & 90 \\
Fibula & 625 & 130 & 80 & 70 \\
\hline Midshaft mediolateral & diameter & $\begin{array}{c}\text { Minimum midshaft } \\
\text { circumference }\end{array}$ & Distal end anteroposterior \\
diameter & 270 & 160 & $\begin{array}{c}\text { Distal end mediolatreal } \\
\text { diameter }\end{array}$ \\
\hline Fibula & 70 & 195 & 115 & 125 \\
\hline \hline
\end{tabular}


tasaura (MPCA 460), differing from the short and stout morphology ( $\mathrm{RI} \geq 0.31$ ) seen in saltasaurines.

Proximally, the tibia presents an ovoid outline as in most sauropods, although more lateromedially expanded than in other titanosaurs such as Bonitasaura and Rapetosaurus, but not as expanded as in derived titanosaurs (e.g., Neuquen- saurus, Opisthocoelicaudia). In lateral view, the proximal end is mostly rounded. The cnemial crest is triangular, well developed, and faces laterally as in most sauropods. The concave surface behind the cnemial crest - where the proximal fibula articulates- is deep and extends distally more than one third the total length of the tibia; it thus differs from the
(1)

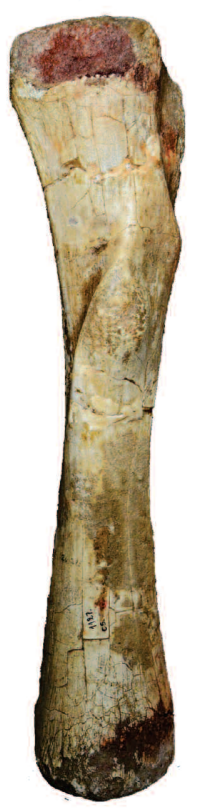

(2)



8



(3)



10

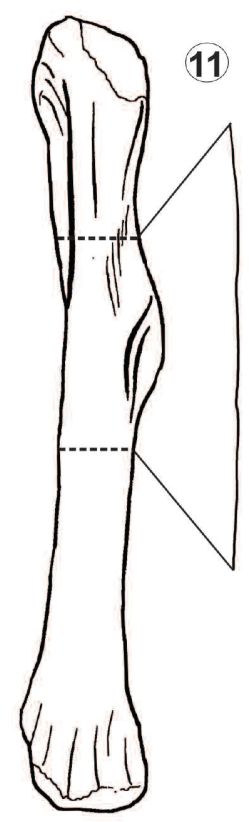

5



(6)

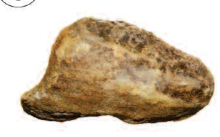

(7)



$(12$

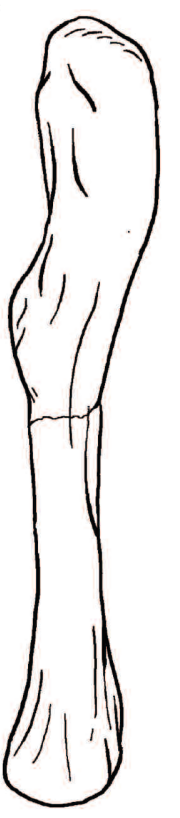

13

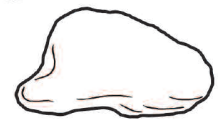

(14)



Figure 3. Laplatasaurus araukanicus lectotype, MLP-CS 1127; 1, 8, right fibula in lateral view; 2 , 9, medial view; 3, 10, posterior view; 4, 11, detail of posterior view; 5, 12, anterior view; 6, 13, proximal view; 7, 14, distal view. Abbreviations: af, anteroproximal fossa; am, anteroproximal margin; It, lateral tuberosity; tf, tuberosity fossa. 
shorter surface (less than one third the total length) seen in other titanosaurs with slender tibiae such as Bonitasaura, Antarctosaurus, Rapetosaurus, Opisthocoelicaudia, and Jainosaurus -and constitutes an autapomorphy of Laplatasaurus (Fig. 4). Although a similar condition is present in Neuquensaurus and Saltasaurus, these have robust tibiae. The tibial protuberance (sensu Salgado and Carvalho, 2008) located posterolaterally to the cnemial crest and behind the cnemial fossa is not well developed, unlike the well-developed protuberance present in Uberabatitan (Salgado and Carvalho, 2008: fig. 19B) and Opisthocoelicaudia (Borsuk-Bialynicka, 1977: pl. 14). Likewise, a projection posterior to the cnemial crest (the 'second cnemial crest' of Bonaparte et al., 2000) is absent. The shaft is longer anteroposteriorly than lateromedially, rendering the elliptical cross-section of most sauropods. In anterior view, the minimum width of the shaft is located at mid-length and the proximal and distal ends expand in the same proportions.

Distally, the lateral and posterior condyles are slightly deteriorated and rounded. The posterior condyle is located below the distal level of the lateral one. The typical groove between the two condyles is not preserved; thus, in distal view the perimeter is sub-triangular.

Fibula. The right fibula is also part of the lectotype of Laplatasaurus araukanicus (Fig. 3). Its size and perfect articulation with the previously described tibia suggest that this element belongs to the same specimen [as previously suggested by Huene (1929a) and Bonaparte and Gasparini (1979)]. This bone is slender (RI: 0.16), with slightly expanded epiphyses and an almost straight shaft. The straightness of a sauropod fibula considers the angle of the proximal and distal surfaces with respect to the shaft in lateral view (Royo-Torres, 2009). The shaft is straight in lateral view as in Uberabatitan (Salgado and Carvalho, 2008), differing from the somewhat sigmoid ones of Epachthosaurus (Martínez et al., 2004), Tastavinsaurus (Canudo et al., 2008), Bonitasaura (MPCA 467), Jainosaurus (Wilson et al., 2011), Rapetosaurus (Curry Rogers, 2009), Neuquensaurus (Otero, 2010), and Saltasaurus (PVL 417). Such a sigmoidal outline is caused by the presence of posterior concave and convex margins above and below the lateral tuberosity, respectively (Fig. 5). Proximally, a pronounced anterior depression develops above the level of the anterior trochanter (sensu Wilson and Sereno, 1998). This fossa is notably developed in Laplatasaurus and it is laterally framed by a thick margin with a concave outline. Although less developed, a similar fossa and margin are present in Uberabatitan (Salgado and Carvalho, 2008, fig. 19G), Mendozasaurus (González Riga, 2003, fig. 6B), Jainosaurus (Wilson et al., 2011), and Opisthocoelicaudia (Borsuk-Bialynicka, 1977). Such a fossa was proposed by Borsuk-Bialynicka (1977) as the osteological correlate of the iliofibularis muscle, although that author described it proximally on the posterior wall of the fibula (note that the

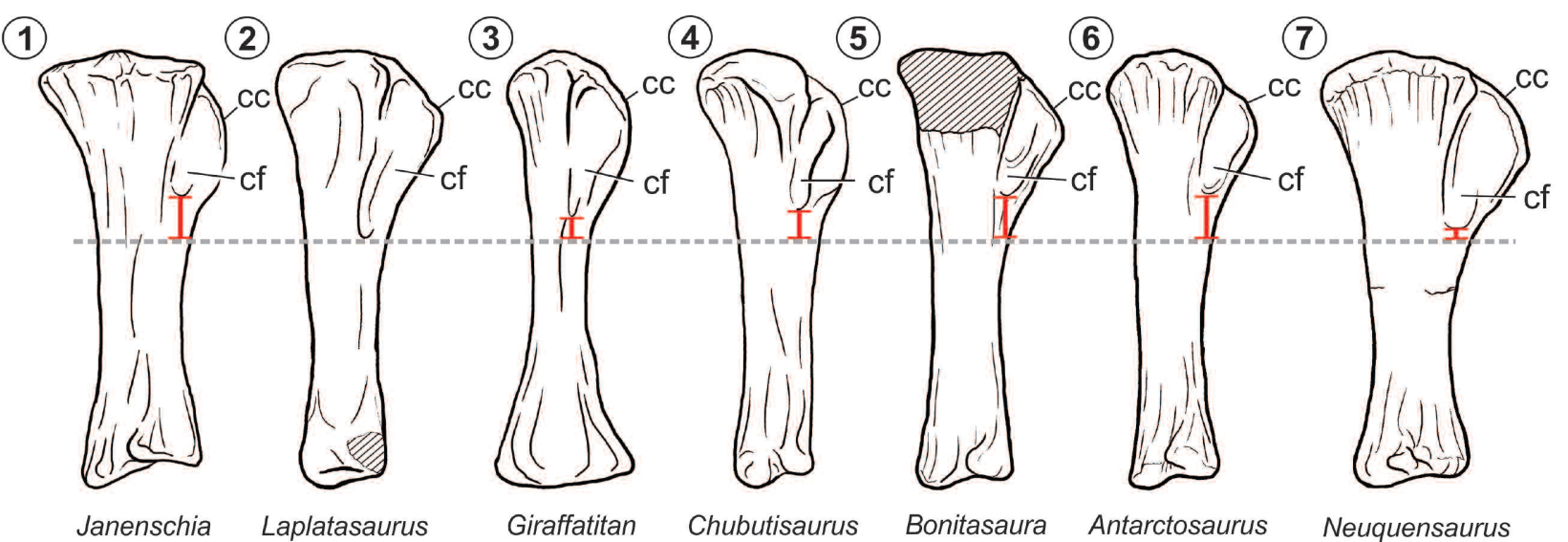

Figure 4. Comparative tibiae of various titanosauriforms in lateral view. 1, Janenschia SMNS 12144; 2, Laplatasaurus MLP-CS 1128; 3, Giraffatitan MB.R 3689; 4, Chubutisaurus MACN 18222; 5, Bonitasaura MPCA 460; 6, Antarctosaurus MACN 6804; 7, Neuquensaurus MCS- 6. Antarctosaurus and Giraffatitan reversed from the left. Gray/red dotted line denotes the ventral extent of the cnemial fossa. Abbreviations: cc, cnemial crest; cf, cnemial fossa. 
(1)



Janenschia

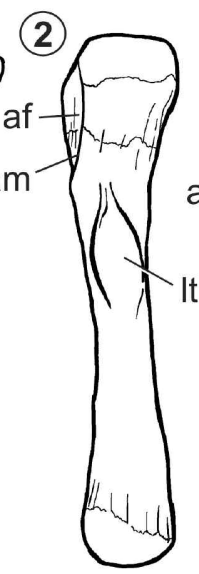

Laplatasaurus
(3)

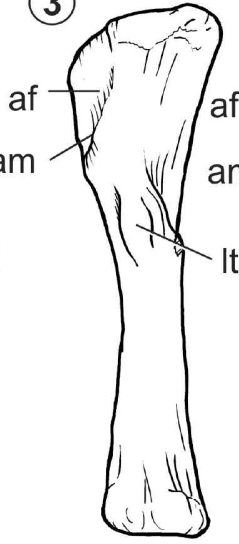

Uberabatitan
(4)



Mendozasaurus
(5)



Epachthosaurus
(6)



Rapetosaurus



Neuquensaurus



Saltasaurus

Figure 5. Comparative fibulae of various titanosauriforms in lateral view. 1, Janenschia SMNS 12144; 2, Laplatasaurus MLP-CS 1127; 3, Uberabatitan CPP-1107-UrHo; 4, Mendozasaurus; 5, Epachthosaurus; 6, Rapetosaurus FMNH PR 2209; 7, Neuquensaurus MLP-CS 1265; 8, Saltasaurus PVL 401785. Abbreviations: af, anteroproximal fossa; am, anteroproximal margin; It, lateral tuberosity. Janenschia and Laplatasaurus reversed from the right. Mendozasaurus taken from González Riga (2003, fig. 6B), Epachthosaurus taken from Martínez et al. (2004, fig. 12C). Scale bar $=10 \mathrm{~cm}$.

figured right fibula is in fact a left one in Borsuk-Bialynicka, 1977, fig. 16A). However, in extant crocodiles this muscle is inserted in a tuberosity placed in the proximolateral surface of the fibula (Meers, 2003; Otero et al., 2010), a topological equivalent to the titanosaurian lateral tuberosity (Otero and Vizcaíno, 2008).

The lateral tuberosity is well developed, oriented from the anteroproximal to posterodistal sides, and located at mid-length of the bone, as in most titanosaurs. Differing from the flat posterior surface present in most titanosaurs, a longitudinal concave surface behind the lateral tuberosity is recognized in Laplatasaurus, such as occurring also in Uberabatitan. Powell (2003, p. 23) stated that a double lateral tuberosity is present and diagnostic for Laplatasaurus, an opinion also shared by Wilson and Upchurch (2003, p. 143). Nonetheless, based on the descriptions provided by Powell (2003. p. 23) in which "the remaining prominence stands out marking the inferior part of the plate situated in the anterosuperior angle of the proximal area", we infer that this tuberosity corresponds to the ventral tip of the anteroproximal thick margin and not to part of the lateral tuberosity.

The distal portion of the fibula is rounded, except for the flat surface developed on the medial face, which corresponds to the astragal contact.

\section{TAXONOMIC STATUS OF MATERIALS PREVIOUSLY REFERRED TO LAPLATASAURUS}

Material from Lydekker's collection. This material includes dorsal centra, a right humerus, and a right femur. Huene (1929a) referred several specimens from Lydekker's collection [originally assigned to 'Titanosaurus' (=Neuquensaurus) australis] to Laplatasaurus araukanicus (Supplementary Online Information Tab. 1) based on observed differences in proportions and morphology- with other specimens from Cinco Saltos assigned to 'Titanosaurus' australis. However, this assignation is not supported because of the lack of overlapping elements with the lectotype. Besides, that material comes from a locality [close to Neuquén city (Lydekker, 1893)] different from that of the lectotype of Laplatasaurus araukanicus. Summarizing, the presence of well-developed ovoid pneumatic foramina in the opisthocoelic dorsal centrum, an extended deltopectoral crest in the humerus, and an anteroposteriorly compressed shaft, in addition to beveled distal condyles of the femur suggest at least that these materials belong to Lithostrotia indet.

Material from Cinco Saltos. Besides the tibia and fibula selected as lectotype (Bonaparte and Gasparini, 1979), several additional remains assigned to Laplatasaurus araukanicus by Huene (1929a) are housed in the La Plata Museum (Supplementary Online Information Tab. 1). Unfortunately, a 
great number of these elements are missing and only a few vertebrae (mostly distal caudals), a fragmentary sternal plate, a right scapula, fragmentary humerus and radius, a metacarpal, fragment of an ilium, and a metatarsal are available for study. None of the latter can be assigned to Laplatasaurus araukanicus with certainty and is not possible to say that those materials come from the same site as the lectotype, since the locality includes multiple excavating sites (Huene, 1929a, p. 12). The glenoid surface of the scapula deflected to face anteroventrally and medially and the deep concave area on the posterior face of the distal humerus suggest that this material may be referred to Lithostrotia indet.

Material from Rancho de Ávila. There is a great amount of remains from this locality (Supplementary Online Information Tab. 1), all collected by a team from the La Plata Museum led by the paleontologist Santiago Roth and the geologist Walter Schiller during 1921 and 1922; the material comes from probably a single excavation site (Huene, 1929a, p. 5). The material belongs to more than one specimen of midsized sauropods. Incomplete remains of a tibia (MLP-Av 2062) and fibulae [MLP-Av 2074, MLP-Av 2060 (these materials were not mentioned by Huene, but correspond to the same collection)] allow a comparison with the lectotype of Laplatasaurus araukanicus. Although fragmentary, the proximal tibia from Rancho de Ávila has a more quadrangular perimeter in proximal view and a shorter concave surface on the lateral aspect. Both fragments of fibulae from Rancho de Ávila lack the marked anteroproximal concave margin over the lateral trochanter, differing from the condition present in Laplatasaurus araukanicus.

Although briefly mentioned, Huene (1929a, p. 5, 13) provided stratigraphic and geographic information on the site in which this material was found. This information strikingly matches the same stratigraphic level (top of the Bajo de la Carpa Formation) and the same geographic region where the titanosaur Bonitasaura salgadoi was found in 2003 (Apesteguía, 2004; Pérez et al., 2009). Besides, some anatomical traits and the preservation conditions link the materials collected at Rancho de Avila with Bonitasaura (Gallina, 2011a, p. 294; fig. 112). A well-preserved anterior dorsal neural arch (MLP-Av 2121) shows a low and triangular neural spine with robust spinodiapophyseal laminae and spinoprezygapophyseal laminae as in the first dorsal of
Bonitasaura (Gallina, 2011b; Gallina and Apesteguía, 2015). The anterior caudal neural spine (MLP-Av 1007) also shows similarities with Bonitasaura as revealed by the presence of thin longitudinal laminae diverging from the anterior median lamina and postspinal lamina (Fig. 6). The latter represents an autapomorphy of Bonitasaura (Gallina and Apesteguía, 2011). This situation, plus the mentioned similarities in both preservation and morphology, and assuming the monospecificity of a single quarry, allows the assignation of the material from Rancho de Ávila to cf. Bonitasaura sp.

Material from Río Neuquén. Huene (1929a, p. 55) assigned to Laplatasaurus araukanicus a series of ten caudal vertebrae (MLP-26-28, although eleven are preserved in MLP collection, see also Powell, 2003: PI. 6) from the right bank of the Neuquén River, near Neuquén city [probably Bajo de la Carpa Formation (Bonaparte and Gasparini, 1979)]. The lack of overlapping elements with the lectotype of Laplatasaurus araukanicus precludes comparisons with this species. The general morphology of the caudal series renders some valuable taxonomic information. These elements present procoelous centra, neural arches located in the mid-anterior half of the centrum length, and prezygapophyses projected anteriorly as in most titanosaurs. The anterior margins of anterior and middle centra are almost straight and the preserved neural spines (in anterior and middle vertebrae) are also straight, which discards their assignation to Aeolosaurini (sensu Franco-Rosas et al., 2004).

Considering the absence of diagnostic characters at a generic level together with all the features mentioned above we refer this caudal series to Lithostrotia indet.

Material from General Roca. Some of the material collected by Wichmann in 1912 in outcrops of the Anacleto Formation, was later assigned to Laplatasaurus araukanikus by Huene (1929a). It includes an anterior caudal vertebra, five distal caudal centra, a radius, a distal ulna, a complete metacarpus, a distal tibia, and two metatarsals, which are housed in MACN. The only material comparable with the lectotype is the distal tibia, but no diagnostic features are present. Thus, the assignation of this material to Laplatasaurus araukanikus is not possible. However, the presence of a biconvex anterior and distal caudal, a broad distal radius and a U-shaped metacarpus formed by slender metacarpals with flat distal condyles suggests that this material may belong in Lithostrotia indet. 

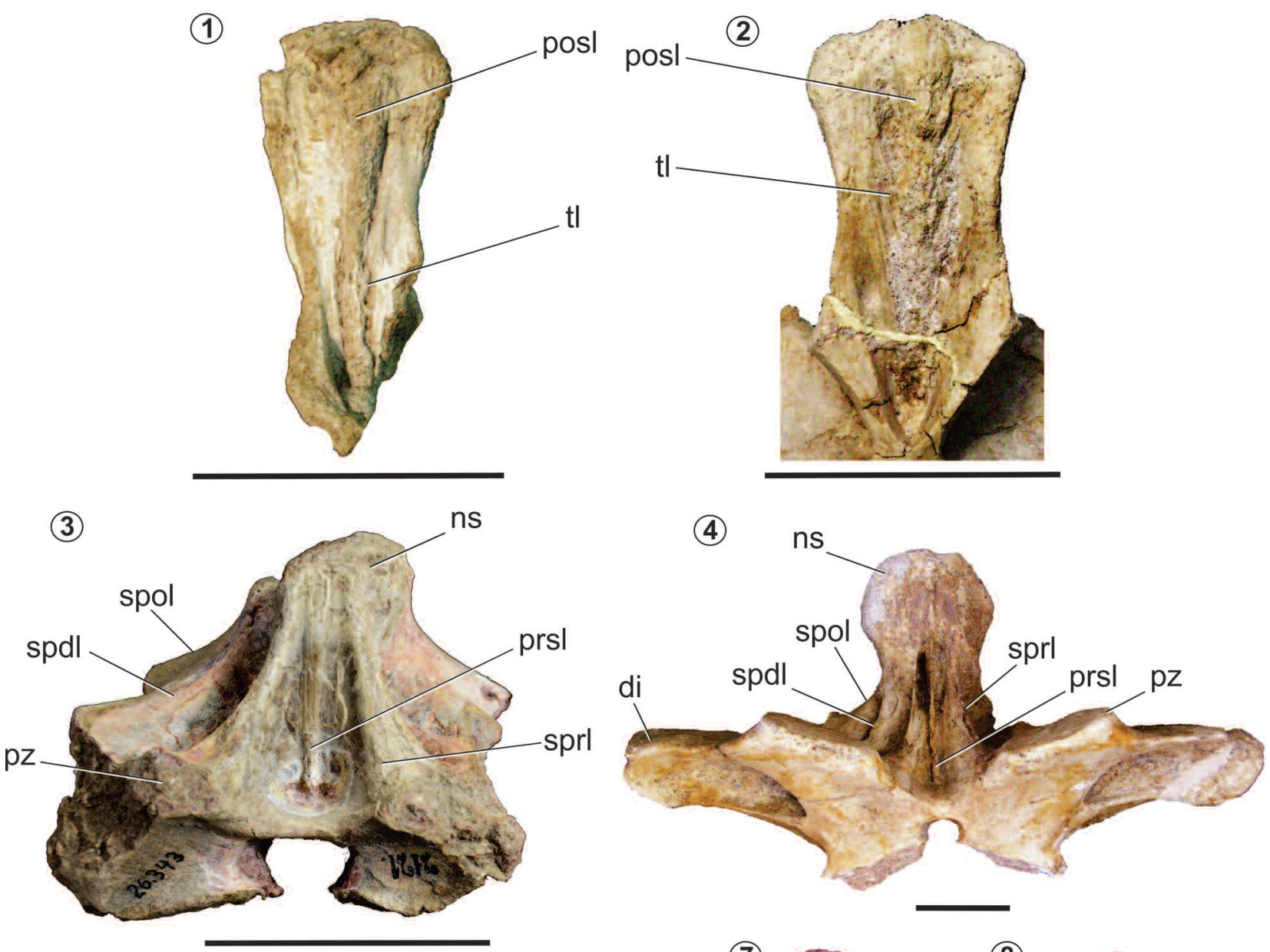

(5)


Figure 6. Comparative elements from Rancho de Avila and Bonitasaura salgadoi. 1, anterior caudal neural spines in posterior view of MLP-Av1007; 2, anterior caudal neural spines in posterior view of Bonitasaura MPCA-460; 3, dorsal neural arches of MLP-Av-2121; 4, dorsal neural arches of Bonitasaura MPCA-460; 5, proximal fibula of MLP-Av-2060 (lateral view); 6, proximal fibula of the same specimen (posterior view); 7, fibula of Bonitasaura MPCA-467 (lateral view); 8, fibula of the same specimen (posterior view). Abbreviations: di, diapophysis; It, lateral tuberosity; ns, neural spine; posl, postpinal lamina; prsl, prespinal lamina; pz, prezygapophysis; spdl, spinodiapophyseal lamina; spol, spinopostzygapophyseal lamina; sprl, spinoprezygapophyseal lamina; tl, thin laminae. Scale bar $=10 \mathrm{~cm}$. 
Material from Uruguay. Huene (1929b; 1931) referred to Laplatasaurus araukanicus two caudal vertebrae, a sternal plate and a distal femur from Arroyo La Lancha (Soriano Department, Uruguay). However, those assignations were not properly justified based on diagnostic characters. Besides, neither anatomical descriptions nor figures were provided. Powell (2003) suggested that it was impossible to refer this material to a genus because of the fragmentary nature of the bones (some of the material is currently missing, thus the diagnostic characters can not be checked) and referred it to Titanosauridae indet. based on the morphology of the caudal elements. We agree with this assignation.

Material from Cinco Saltos. In 1975, Roberto Abel from the MPCA found an articulated tail composed of 27 vertebrae in an industrial quarry belonging the INDUPA company, a few kilometers east from Cinco Saltos city, Río Negro Province (Anacleto Formation; see Powell 2003, map 4). This specimen (MPCA 1501) was later considered by Powell (2003) as part of the hypodigm of 'Titanosaurus' araukanicus, although a clear justification for such an assumption was not established. We understand that the author found similarities between those caudal vertebrae and those described by Huene (1929a) as belonging to the materials of Laplatasaurus araukanicus (the series from Río Neuquén). However, there are no diagnostic features to support the assignation of those elements to Laplatasaurus araukanicus, as this taxon is diagnosed by means of characters drawn from the appendicular bones. Later, Salgado and García (2002) analyzed some morphological traits in the titanosaurid caudal vertebrae, mentioning such a caudal series as 'Titanosaurus' araukanicus following Powell's assignation. Unfortunately, almost all of that material was stolen from the MPCA collection in 2004, and only two anterior caudal vertebrae are still available for study. The tall caudal centrum with slightly concave lateral walls and a compressed ventral face allow a clear differentiation from the caudal vertebrae of other taxa from the same geographic area such as Neuquensaurus and Pellegrinisaurus. Yet, the assignation to Laplatasaururus araukanicus is not warranted because of the lack of association with appendicular bones. We suggest the assignation to Lithostrotia indet. as more appropriate.

Material from Arroyo Morterito. Arroyo Morterito is located in the Candelaria Department (Salta Province, Argentina) and the fossil-bearing bed is at the top of the Late Creta- ceous Los Blanquitos Formation (Powell, 1979; Powell, 2003). Sauropod remains from this locality were collected by Powell in 1975 and described a few years later (Powell, 1979). These remains include a fragment of premaxilla and elements of vertebrae and limbs that Powell referred to Laplatasaurus sp.. A very fragmentary tibia and fibula were described, but these show no diagnostic features of Laplatasaurus. The general morphology and proportions of limb elements, and the presence of laterally compressed procoelous caudal vertebrae, with short neural arches restricted to the anterior halves suggested their inclusion in Lithostrotia indet., in agreement with the assignation by Powell (2003).The premaxilla preserves one functional tooth and three replacement teeth (PVL-3670-12). Although the teeth are broad-crowned, a condition observed in basal macronarians from the Upper Jurassic and Lower Cretaceous, this tooth morphology was also recorded in Late Cretaceous forms such as the titanosaur Ampelosaurus (MDE-C3-52) and other forms from Patagonia (Gallina et al., 2010), thus supporting the taxonomic assignation to Lithostrotia.

\section{PHYLOGENETIC ANALYSIS}

Laplatasaurus araukanicus was not included in previous phylogenetic analyses because of the uncertainty surrounding the material referred to the genus. Considering that only the lectotype can be confidently assigned to this species, we explore here the impact of the postcranial information provided by MLP-CS 1127 and MLP-CS 1128 on the phylogenetic relationships of titanosaurs. This topic is explored using a modified version of a recent data matrix for titanosaurs published by Salgado et al. (2015), including ten characters taken from other sauropod data matrixes plus two new characters proposed here, and two taxa (Uberabatitan riberoi and Overosaurus paradasorum), adding up to a total of 88 characters scored across 26 taxa (Supplementary Online Information Data Matrix and List 1). The dataset includes some forms outside Titanosauria, which represent the outgroups, including a basal camarasauromorph (Camarasaurus), and two basal titanosauriforms (Giraffatitan and Chubutisaurus). Most characters are binary, but 18 are multistate and were treated as unordered. An equally weighted parsimony analysis was carried out using TNT v.1.1 (Goloboff et al., 2008 a, b). A heuristic tree search was performed 
consisting of 1000 replicates of Wagner trees (with random addition sequence of taxa) followed by branch swapping (TBR; saving 100 trees per replicate). This procedure retrieved 61 most parsimonious trees of 176 steps $(C l=0.59$; $\mathrm{RI}=0.66)$, found in 431 out of the 1000 replicates. A strict consensus tree collapsed into a polytomy at the base of $\mathrm{Ti}-$ tanosauria, although preserved well-supported derived groups such as Aeolosaurini and Saltasaurini (sensu Salgado and Bonaparte, 2007). When Nemegtosaurus (known from an isolated complete skull) is removed from the consensus a better resolution is achieved, recovering the clade (Alamosaurus + Opisthocoelicaudia) and Rapetosaurus as the sister taxon of the clade (Overosaurus + Aeolosaurini) + more derived titanosaurs (Fig. 7).

Laplatasaurus is recovered together with Uberabatitan in a clade supported by the presence of a longitudinal fossa on the posterior face of the fibular midshaft [character 87 (1)]. Aeolosaurini is supported by the presence of mid-caudal centra with the anterior face strongly inclined anteriorly [character 46 (1)], whereas three synapomorphies support Saltasaurini: anterior and middle caudal centra wider than high [character 45 (1)], anterodorsal border of neural spine in middle caudal vertebrae located posteriorly with respect to anterior border of the postzygapophyses [character 50 (1)], and robust tibia [character 75 (1)]. Finally, the clade composed by (Bonitasaura (Futalognkosaurus + Mendozasaurus)) is supported by four synapomorphies: posterior cervical neural spines laterally expanded and wider than the centra [character 24 (1)], posterior cervical vertebrae taller than long [character 27 (1)], deep and extended spinodiapophyseal fossa



Figure 7. Reduced consensus tree to show Titanosauria interrelationships (excluding Nemegtosaurus). Support values are given as follows: Bremer (more than 2), Bootstrap (more than 50), and Jackniffe (more than 50). 
in posterior cervical vertebrae [character 28 (2)], and wide and well developed iliac pedicel of ischium [character 68 (2)].

Support values are invariably low, showing a Bremer value of 2 and Bootstrap and Jacknife values over 50 only for Titanosauria and Saltasaurini.

\section{CONCLUSION}

Most of the pioneering descriptions of sauropods from Patagonia (e.g.' 'Titanosaurus' (=Neuquensaurus) australis, Antarctosaurus wichmannianus, and Laplatasaurus araukanicus) were based on abundant material collected during several field missions and from more than one locality (Lydekker, 1893; Huene, 1929a; Salgado, 2007). As was common at that time, most of them did not include quarry maps with skeletal associations, designation of type material, and/or supported diagnoses based on autapomorphic traits. Thus, the taxonomic status of the taxa remained problematic. Only new findings of associated materials (e.g., Neuquensaurus australis, Salgado et al., 2005) or taxonomic revisions (Otero, 2010; D'Emic and Wilson, 2011; Mannion and Otero, 2012) aided in resolving many issues and thus allowed a phylogenetic analysis of the taxa.

In this sense, an in-depth study of Laplatasaurus araukanicus and all previously referred material suggested restricting the species only to the lectotype designated by Bonaparte and Gasparini (1979). This was previously suggested by Wilson and Upchurch (2003), who included in the type material a right tibia and fibula from Cinco Saltos. This was possible because of the recognition of two autapomorphic characters (tibia with deep cnemial fossa, extending more than one third the length of the shaft and fibula with extremely developed anterior fossa at the proximal end, laterally bounded by a thick margin) and the absence of overlapping elements with the lectotype, which precluded comparisons. In this sense, the remaining elements coming from Lydekker's collection, Cinco Saltos, Río Neuquén, General Roca, and Arroyo Morterito present features that allowed us to include them in Lithostrotia. The materials from Rancho de Ávila were assigned to cf. Bonitasaurasp.

Restricting Laplatasaurus araukanicus only to the lectotype allowed us to include this species in a phylogenetic analysis for the first time. Although the support values of the in-group nodes are invariably low, this species is recovered as the sister taxon of the latest Cretaceous Brazilian taxon
Uberabatitan riberoi, nested within Titanosauria in a clade formed by ((Laplatasaurus + Uberabatitan) + (Bonitasaura + (Futalognkosaurus + Mendozasaurus))). New findings of articulated or associated materials with diagnostic data should help testing our phylogenetic results.

\section{ACKNOWLEDGEMENTS}

We would like to thank M. Reguero (MLP) and J. Powell (PVL) for collection access and for discussion on the assignation of several materials analyzed here. I. Cerda (MPCA) and J. Powell provided important information on specimens housed in MPCA. We thank $P$. Mannion, M. D'Emic and J. L. Carballido for their critical reviews on the manuscript. Finally, L. Acosta (MLP) is thanked for restoring the lectotype of Laplatasaurus araukanicus.

\section{REFERENCES}

Apesteguía, S. 2004. Bonitasaura salgadoi gen. et sp. nov.: a beaked sauropod from the Late Cretaceous of Patagonia. Naturwissenschaften 91: 493-497.

Barrett, P.M., and Upchurch, P. 2005. Sauropodomorph diversity through time. Paleoecological and macroevolutionary implications. In: C.C. Rogers, and J.A. Wilson (Eds.), The sauropods: evolution and paleobiology. University of California Press, California, p. $104-124$.

Bonaparte, J.F. 1996. Cretaceous tetrapods of Argentina. Münchner Geowissenchaftliche Abhandlungen Reihe A, Geologie und Paläeontologie 30: 73-130.

Bonaparte, J.F., and Coria, R.A. 1993. Un nuevo y gigantesco saurópodo titanosaurio de la Formación Río Limay (Albiano-Cenomaniano) de la Provincia del Neuquén, Argentina. Ameghiniana 30: 271-282.

Bonaparte, J.F., and Gasparini, Z.B. 1979. Los saurópodos de los grupos Neuquén y Chubut, y sus relaciones cronológicas. $5^{\circ}$ Congreso Geológico Argentino (Neuquén), Actas 2: 39-406.

Bonaparte, J.F., Heinrich, W.D., and Wild, R. 2000. Review of Janenschia Wild, with the description of a new sauropod from the Tendaguru beds of Tanzania and a discussion on the systematic value of procoelous caudal vertebrae in the Sauropoda. Palaeontographica, Abteilung A, Paläozoologie -Stratigraphie 256: 25-76.

Borsuk-Bialynicka, M. 1977. A new camarasaurid sauropod Opisthocoelicaudia skarzynskiigen. n. sp. n. from the Upper Creataceous of Mongolia. In: Z. Kielan-Jaworowska (Ed.), Results of the Polish-Mongolian Paleontological Expeditions. Palaeontologia Polonica 37: 5-64.

Canudo, J.I., Royo-Torres, R., and Cuenca-Bescós, G. 2008. A new sauropod: Tastavinsaurus sanzi gen. et sp. nov. from the early Cretaceous (Aptian) of Spain. Journal of Vertebrate Paleontology 28: 712-731.

Cerda, I.A., Paulina Carabajal, A., Salgado, L., Coria, R.A., Reguero, M.A., Tambussi, C.P., and Molly, J.J. 2012. The first record of a sauropod dinosaur from Antarctica. Naturwissenschaften 99: 83-87.

Curry Rogers, K.A. 2009. The postcranial osteology of Rapetosaurus krausei (Sauropoda: Titanosauria) from the Late Cretaceous of Madagascar. Journal of Vertebrate Paleontology 29: 1046-1086.

D'Emic, M.D., and Wilson, J.A. 2011. New remains attributable to the holotype of Neuquensaurus australis (Dinosauria: Sauropoda): implications for saltasaurine systematics. Acta Palaeontologica Polonica 56: 61-73. 
Franco-Rosas, A.C., Salgado, L., Rosas, C.F., and Carvalho, I.S. 2004. Nuevos materiales de titanosaurios (Sauropoda) en el Cretácico Superior de Mato Grosso, Brasil. Revista Brasileira de Paleontologia 7: 329-336.

Gallina, P.A. 2011a. [Estudio anatómico, sistemático y paleobiológico de Bonitasaura salgadoi (Dinosauria, Sauropoda): su importancia en el contexto de la evolución delos titanosaurios del Cretácico Superior de la Argentina. Tesis Doctoral, Facultad de Ciencias Naturales y Museo, Universidad Nacional de La Plata, 340 p. Unpublished.].

Gallina, P.A. 2011b. Notes on the axial skeleton of the titanosaur Bonitasaura salgadoi (Dinosauria-Sauropoda). Anais da Academia Brasileira de Ciências 83: 235-245.

Gallina, P.A., Apesteguía, S. 2011. Tunasniyoj, a dinosaur tracksite from the Jurassic-Cretaceous boundary of Bolivia. Anais da Academia Brasileira de Ciências 83: 267-277.

Gallina, P.A., and Apesteguía, S. 2015. Postcranial anatomy of Bonitasaura salgadoi (Sauropoda: Titanosauria) from the Late Cretaceous of Patagonia. Journal of Vertebrate Paleontology 35: 1-22.

Gallina, P.A., and Apesteguía, S., and Gianechini, F.A. 2010. Primitive broad-crowned titanosaurs in the Uppermost Cretaceous? Ameghiniana 47: 12R.

Goloboff, P.A., Farris, J.S., and Nixon, K. 2008a. A free program for phylogenetic analysis. Cladistics 24: 774-786.

Goloboff, P.A., Farris, J.S., and Nixon, K. 2008b. TNT: Tree Analysis Using New Technology, vers. 1.1 (Willi Hennig Society Edition). World Wide Web: http://www.zmuc.dk/public/phylogeny/tnt

González Riga, B.J. 2003. A new titanosaur (Dinosauria, Sauropoda) from the Upper Cretaceous of Mendoza Province, Argentina. Ameghiniana 40: 155-172.

Huene, F. Von. 1929a. Los Saurisquios y Ornitisquios del Cretáceo Argentino. Museo de la Plata, Anales 3: 194 p.

Huene, F. Von. 1929b. Terrestrische Oberkreide in Uruguay. Centralblatt für Mineralogie, Geologie und Paläontologie Abteilung B 1929: 107-112.

Hunt, A.P., Lockley, M.G., Lucas, S.G., and Meyer, C.A. 1994. The global sauropod fossil record. Gaia 10: 261-279.

Jianu, C.M., and Weishampel, D.B. 1999. The smallest of the largest: a new look at possible dwarfing in sauropod dinosaurs. Geologie en Mijnbow 78: 335-343.

Kellner, A.W.A., and Azevedo, S.A.K. 1999. A new sauropod dinosaur (Titanosauria) from the Late Cretaceous of Brazil. Proceedings of the Second Gondwana Symposium 15: 111-142.

Leanza, H.A. 1999. The Jurassic and Cretaceous Terrestrial Beds from southern Neuquén Basin, Argentina. Instituto Superior de Correlación geológica (INSUGEO), Miscelánea 4: 30 p.

Leanza, H.A., and Hugo, C.A. 2001. Cretaceous red beds from southern Neuquén Basin (Argentina): age, distribution and stratigraphic discontinuities. $7^{\circ}$ International Symposium on Mesozoic Terrestrial Ecosystems, Asociación Paleontológica Argentina Special Paper 7: 117-122.

Leanza, H.A., Apesteguía, S., Novas, F.E., and de la Fuente, M.S. 2004. Cretaceous terrestrial beds from the Neuquén Basin (Argentina) and their tetrapod assemblages. Cretaceous Research 25: 61-87.

Lydekker, R. 1893. Contributions to the study of the fossil vertebrates of Argentina. I. The dinosaurs of Patagonia. Anales del Museo de la Plata, Sección de Paleontología 2: 1-14.

Mannion, P.D., and Otero, A. 2012. A reappraisal of the Late Cretaceous Argentinean sauropod dinosaur Argyrosaurus superbus, with a description of a new titanosaur genus. Journal of Vertebrate Paleontology 32: 614-638.

Marsh, O.C. 1878. Principal characters of American Jurassic di- nosaurs. Part I. American Journal of Science 16: 411-416.

Martínez, R.D., Giménez, O., Rodriguez, J., Luna, M., and Lamanna, M.C. 2004. Anarticulated specimen of the basal titanosaurian (Dinosauria: Sauropoda) Epachthosaurus sciuttoi from the early Late Cretaceous Bajo Barreal Formation of Chubut Province, Argentina. Journal of Vertebrate Paleontology 24: 107-120.

Mazzetta, G.V., Christiansen, P., and Fariña, R.A. 2004. Body size in some southern South American cretaceous dinosaurs. Historical Biology 16: 71-83.

McIntosh, J.S. 1990. Sauropoda. In: D.B. Weishampel, P. Dodson, and H. Osmólska (Eds.), The Dinosauria. University of California Press, Berkeley, p. 345-401.

Meers, M.B. 2003. Crocodylian forelimb musculature and its relevance to Archosauria. The Anatomical Record Part A 274: 892-916.

Otero, A. 2010. The appendicular skeleton of Neuquensaurus, a Late Cretaceous saltasaurine sauropod from Patagonia, Argentina. Acta Palaeontologica Polonica 55: 299-326.

Otero, A., and Vizcaíno, S.F. 2008. Hindlimb musculature and function of Neuquensaurus australis (Sauropoda: Titanosauria). Ameghiniana 45: 333-348.

Otero, A., Gallina, P.A., and Herrera, Y.L. 2010. Pelvic musculature and function of Caiman latirostris. Herpetological Journal 20: 173-184.

Owen, R. 1842. Report on British fossil reptiles, part II. Report of the British Association for the Advancement of Science 11: 60-204.

Pérez, L.M., Otero, A., Apesteguía, S., and Gallina, P.A. 2009. Estratigrafía y análisis tafonómico de Bonitasaura salgadoi Apesteguía, en el sitio "La Bonita" (Cretácico superior, Río Negro, Argentina). Revista del Museo Argentino de Ciencias Naturales 11: 39-48.

Powell, J.E. 1979. Sobre una asociación de dinosaurios y otras evidencia de vertebrados del Cretácico Superior de la región de La Candelaria, Prov. de Salta, Argentina. Ameghiniana 1-2: 191204.

Powell, J.E. 1986. [Revisión de los titanosaúridos de América del Sur. Tesis Doctoral, Facultad de Ciencias Naturales, Universidad Nacional de Tucumán, Tucumán, 340 p. Unpublished].

Powell, J.E. 2003. Revision of South American titanosaurid dinosaurs: paleobiological, palaeobiogeographical and phylogenetic aspects. Record of the Queen Victoria Museum Launceston 11: 1-173.

Royo-Torres, R. 2009. El saurópodo de Peñarroya de Tastavins. Instituto de Estudios Turolenses-Fundación Conjunto Paleontológico de Teruel-Dinópolis, Monografías Turolenses 6: 1-545.

Salgado, L. 2003. Should we abandon the name Titanosauridae? Revista Española de Paleontología 18: 15-21.

Salgado, L. 2007. Patagonia and the study of its Mesozoic reptiles: a brief history. In: Z. Gasparini, L. Salgado, and R.A. Coria (Eds.), Patagonian Mesozoic Reptiles. Indiana University Press, Bloomington, p. 1-28.

Salgado, L., and Bonaparte, J.F. 2007. Sauropodomorpha. In: Z. Gasparini, L. Salgado, and R.A. Coria (Eds.), Patagonian Mesozoic Reptiles. Indiana University Press, Bloomington, p. 188-228.

Salgado, L., and Carvalho, I.S. 2008. Uberabatitan ribeiroi, a new titanosaur from the Marilia Formation (Bauru group, Upper Cretaceous); Minas Gerais, Brazil. Palaeontology 5: 881-901.

Salgado, L., and García, R.A. 2002. Variación morfológica en la secuencia de vértebras caudales de algunos saurópodos titanosaurios. Revista Española de Paleontología 17: 211-216.

Salgado, L., Coria, R.A., and Calvo, J.O. 1997. Evolution of titanosaurid sauropods I: Phylogenetic analysis based on the postcranial evidence. Ameghiniana 34: 3-32.

Salgado, L., Apesteguía, S., and Heredia, S.E. 2005. A new specimen 
of Neuquensaurus australis, a Late Cretaceous Saltasaurinae titanosaur from North Patagonia. Journal of Vertebrate Paleontology 25: 623-634.

Salgado, L., Gallina, P.A., and Paulina Carabajal, A. 2015. Redescription of Bonatitan reigi (Sauropoda:Titanosauria), from the Campanian-Maastrichtian of the Río Negro Province (Argentina). Historical Biology 27: 525-548.

Upchurch, P., Barrett, P.M., and Dodson, P. 2004. Sauropoda. In: D.B. Weishampel, P. Dodson, and H. Osmólska, (Eds.), The Dinosauria, second edition. University of California Press, Berkeley, California, p. 259-322.

Wichmann, R. 1922. Einige geologische Beobachtungen im östlichen Neuquén und angrenzenden Territorium Río Negro. Geologische Rundschau 13: 326-345.

Wilson, J.A., and Sereno, P.C. 1998. Early evolution and higher-level phylogeny of sauropod dinosaurs. Society of Vertebrate Paleontology, Memoir 5: 1-68.

Wilson, J.A., and Upchurch, P. 2003. A revision of Titanosaurus Lydekker (Dinosauria - Sauropoda), the first dinosaur genus with a 'Gondwanan' distribution. Journal of Systematc Palaeontology 1: $125-160$
Wilson, J.A., Barrett, P.M., and Carrano, M.T. 2011. An associated partial skeleton of Jainosaurus cf. septentrionalis (Dinosauria: Sauropoda) from the Late Cretaceous of Chhota Simla, central India. Palaeontology 54: 981-998.

doi: 10.5710/AMGH.08.06.2015.2911

Submitted: April 16 ${ }^{\text {th }}, 2015$

Accepted: June $8^{\text {th }}, 2015$ 